\title{
Teachers in Brazil: Social Mobility and Elements for Federalism Strategies
}

\author{
Otacilio Antunes Santana \\ Department Biophysics and Radiobiology, Federal University of Pernambuco, Recife, Brazil \\ Email: otacilio.santana@ufpe.br, otaciliosantana@gmail.com
}

Received 20 July 2015; accepted 28 August 2015; published 1 September 2015

Copyright (C) 2015 by author and Scientific Research Publishing Inc.

This work is licensed under the Creative Commons Attribution International License (CC BY). http://creativecommons.org/licenses/by/4.0/

(c) (i) Open Access

\section{Abstract}

This work analyzed the social mobility of graduated teachers and their strategic importance for Brazilian federalism. Four topics oriented our analysis: 1) What is really the attractiveness of teacher profession? Why did secondary students decide to become teachers in Brazil?; 2) Does the academic capital (graduate degree) allow the social mobility?; 3) What is the importance of graduated teachers on social stratification? What is the importance of social mobility for teachers to national plan of education and federalism strategies?; and 4) Would teachers break with the social reproduction? Would teachers stimulate the changing of habitus? Survey and interview were the guide to quantitative, qualitative and literature analysis. In Brazil, from the method perspective of this work the main conclusions were: 1 ) most of the graduated teachers do not obtain a social mobility from undergraduate to exercise of profession; 2) the rise of cultural access by teachers could represent a cultural mobility; 3 ) the teachers are important for federalism strategies by their disposition of live in areas with low Human Development Index and low incomes than other Brazilian professionals; and, 4) the presence of teachers in number per inhabitants related with the low number of homicides per inhabitants.

\section{Keywords}

Egressos, Licenciatura, National Plan of Education, Inequality, Stratification Social

\section{Introduction}

The number of graduated teachers is approximately 2 million in Brazil, which represents nearly 1\% of Brazilian population (INEP, 2015). Graduated teachers analyzed on this work are the licentiates to teaching of undergraduate courses (Licenciatura) that form teachers to secondary education, in diverse knowledge areas: pedagogy (also primary education), chemical, biology, mathematical, geography, history, physics, letters, arts, music, and 
others. Although the quantity of teachers in Brazil is significant, a deficit of teachers in classrooms exists (Gatti, 2010). This could be one factor to attractiveness of teacher profession. Moreover, professional vocation, possible fast employability and easy access to undergraduate courses (lower mention in admission) are cited by literature (Evans, 1993). The expectative to reality (post-graduation) is distant because of the claims described by teachers: low wages, precarious infrastructure of labor, inexistent dialogue between teachers and government, diseases related with labor activities, and moral harassment (Santana, 2011; Santana, 2015). Thus, what is really the attractiveness of teacher profession? Why did secondary students decide to become teachers in Brazil? Would the cause be social mobility?

The main expectative when the people acquired the academic capital (licentiate degree and competences) is generally the mobility: mainly economic and social (Santana, 2013). Why do they want economic mobility? Because of high consumption. Why do they want social mobility? Because they can transit to upper social strata (stature, prestige and power) (Weber, 1946). The social mobility premise needs a frame of reference: a perspective (Meighan, 1986). This perspective could be the family economic and social origin and its destination on social stratification (Davis \& More, 1967), from academic capital. Moreover, this is the main evaluation for professional success and life success actually. In capitalism system, the individual economic rise defines the social and cultural mobility by its capacity to consume (Harvey, 1978). Stature, prestige and power could be generally "bought" intergenerational and intragenerational mobility (e.g. see soccer player and celebrities) (Lopreato \& Hazelrigg, 1970). In some countries, the economic and social rise on strata did not result in cultural mobility (Bourdieu, 1986). In Brazil, for example, on post-neocolonialism (2003-2014) the government facilitated the access to university, to social fellowship programs and to income distribution programs enabled an increase of capacity to consume and rise to high social classes, but the population had not an increase in cultural consumption (e.g. museum, cinema, fair and events not commercial) (Chauí, 2013). The question here is: does the academic capital (graduate degree) allow the social mobility?

In other perspective, the teachers are opinion formers and construction of knowledge mediator, and they would be trying to reduce the inequalities. In addition, this is one function of education on society: the principle of homogeneity (Durkheim, 1956). The homogeneity is utopic because of human complexity, but the educational actions would reduce the distances of strata, and to favor the mobility upward; this is a way to equality. The educators commonly prefer the human development of students than former capital human to system (Havighurst, 1953). The teachers rising between the social classes could be strategic to Brazilian government, because they could mediate knowledge to equality and sustainable development against the consume culture. The worth of status position to teachers would reflect in society to a cultural production (Bourdieu \& Passeron, 1977) and to a knowledge building in local context, according to local features and needs (Freire, 1996). When the higher social status is of celebrities or constructed myths, the society will reproduced this culture or the way to rise the higher class (Benoit-Smullyan, 1944). This is important in the federal projects that would be implicit and explicit (overt and covert) on national strategies (Go, 2000). Thus, the emerged questions here were: what is the importance of graduated teachers on social stratification (their class position)? What is the importance of social mobility for teachers to national plan of education (Brasil, 2014) and federalism strategies?

The education could break the habitus of students and teachers front the social stratification (Bourdieu, 1986). The capitalism system modeled the society for consumption and competition, but individual lifestyle in cities and rural areas broke with capitalism principles in their life (e.g. simple life, minimalism, urban cyclists) (Shumway, 2000). The reduction of consumption is directly proportional with the individual freedom in relation to producer and the government (e.g. tax free) (Freire, 1987). Ontologically, the change of habitus here refers the change from consume lifestyle (to have) to experiences lifestyle (to be) (Featherstone, 1987). The education is fundamental to this, because it softens limit and importance of stature, prestige and power (Weber, 1946). The potentialities of being in front of opportunities and life conditions are more relevant than its capacity to consume. Would teachers break with the social reproduction? Would teachers stimulate the changing of habitus? Thus, the objectives of this work were to discuss the social mobility of graduated teachers and to analyze elements for federalism in Brazil by described questions.

\section{Methods and Analysis}

The social mobility analysis were on three data kinds: Quantitative, Qualitative and Literature Review (Figure 1). At the end, a synthesis was elaborated to emerge elements for federalism discussion on National Plan of Education (Brasil, 2014). The graduated teachers in Brazil were the object of study in this work. 


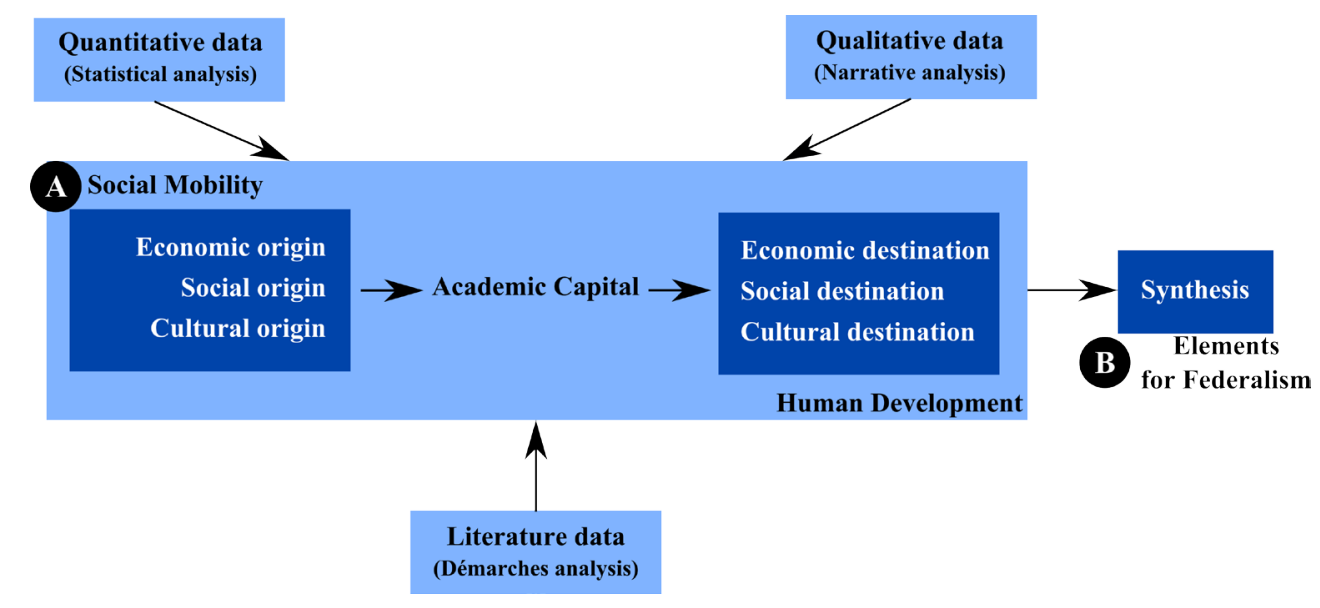

Figure 1. Method scheme.

The teachers graduated from 1996 to 2015 (June) were evaluated by variables Human Development Index (HDI), individual income, economic class, cultural participation and consumption, if they had health insurance plans and if they are homeowners. All these in five times on 20 years: five years before of graduation $(-5)$; on graduation (0); and five (5), ten (10) and fifty years (15) after of graduation. The HDI of states and of neighborhood (where teachers lived and changed) were calculated from IBGE (2015) source data, in according to UNDP (2010). Mean individual income per month; economic class position (Dieese, 2015); insertion in Health insurance plan; and home owners status (if they have or have not own home) were survey in professional council, association and unions. The evaluated unity of income per month was the Brazilian minimum wage (on January 2015: $\mathrm{R} \$ 788 \approx \mathrm{U} \$ 292 \approx € 291$ ). Inter-Union Department of Statistics and Socioeconomic Studies (DIEESE classification about economic class) classified in six classes: upper (above 30 minimum wage); upper-middle (from 20 to 29 minimum wage); lower-middle (from 7 to 19 minimum wage); middle (from 3 to 6 minimum wage); lower (from 1 to 2 minimum wage); and under class (below 1 minimum wage). The cultural participation and consumption was the access per year in cultural institution (e.g. museum, theater and cinema), events (e.g. traditional fair, exposition, and show), and Historic and Artistic Heritage places (e.g. archeological sites and historical landscape). This information were surveyed by individual survey mediated by professional council, association and unions.

Others variables were systematized: homicides per 100,000 inhabitants in Brazilian states (Source data: State Departments of Homicide and Protection, Civil Police) and number of graduated teachers per 100,000 inhabitants (Source data: survey in professional council, association and unions). Homicide rates is an important variable to measure violence and inequality in societies (Morenoff, Sampson, \& Raudenbush, 2001). These variables with HDI and mean individual income per month were vectored on Brazil map with Inkscape vector graphics editor (2015). The family income per month (Source data: IBGE, 2015), mean individual income and number of professionals per 100,000 inhabitants (Source data: survey in professional council, association and unions) were sampled for more three professions: Lawyer, Physician and Engineer. These professions are with more demand by secondary students in Brazilian university admission (MEC, 2015).

The chi-square test was carried out between the class distribution of graduated teachers at 15 years of graduation and the class distribution of others professionals with graduation (all undergraduate courses) to the variables: HDI, mean individual income and economic class. Mann-Whitney test was performed between the cultural access data of teachers with 15 years of graduation and data of others graduated professionals. The exact test of Fisher was performed between the data of teachers at 15 years of graduation and data of others graduated professionals to variables: insertion in health insurance plan and homeowners status. Pearson Correlation (coefficient $=\rho$ ) was performed between the variables HDI, individual income, number of homicides per 100,000 inhabitants, and numbers of teachers per 100,000. Linear regression analysis was applied to relate number of teachers per 100,000 inhabit-ants (y) and HDI (x); and, Homicide per 100,000 inhabitants (y) and numbers of professionals (x), for fours studied professions (Teacher, Lawyer, Physician and Engineer). Coefficient of variation (CV\%) was calculated to analyze the differences between the origin and destination of family income data in each studied profession. All tests were performed at $95 \%$ of confidence and on normal distribution (Shapiro- 
Wilk), according to Zar (1999).

The graduated teachers were interviewed with open questions (Table 1) of all states of Brazil. The main demarches that converged were highlighted of discourses to support the quantitative data analysis (Santana, Silva, Inácio, Oliveira, Silva, \& Encinas, 2013; Santana, 2014). The teachers were contacted by professional council, association and unions of states. The interviews were registered by audio recorder submitted on cloud storage.

\section{Results and Discussion}

The teachers changed to neighborhood with high Human Development Index (HDI) from undergraduate to exercise of profession (Figure 2), but the teachers still lived in sites with low HDI (0.55) than others graduated

Table 1. Open questions of interview.

\begin{tabular}{ll}
\hline Topics \\
1 & $\begin{array}{l}\text { What is really the attractiveness of teacher profession? Why did secondary students decide become teachers in Brazil? } \\
\text { Would the cause be social mobility? }\end{array}$ \\
3 & $\begin{array}{l}\text { Does the academic capital (graduate degree) allow the social mobility? } \\
\text { What is the importance of graduated teachers on social stratification (their class position)? What is the importance of social }\end{array}$ \\
4 & Would teachers break with the social reproduction? Would teachers stimulate the changing of habitus?
\end{tabular}
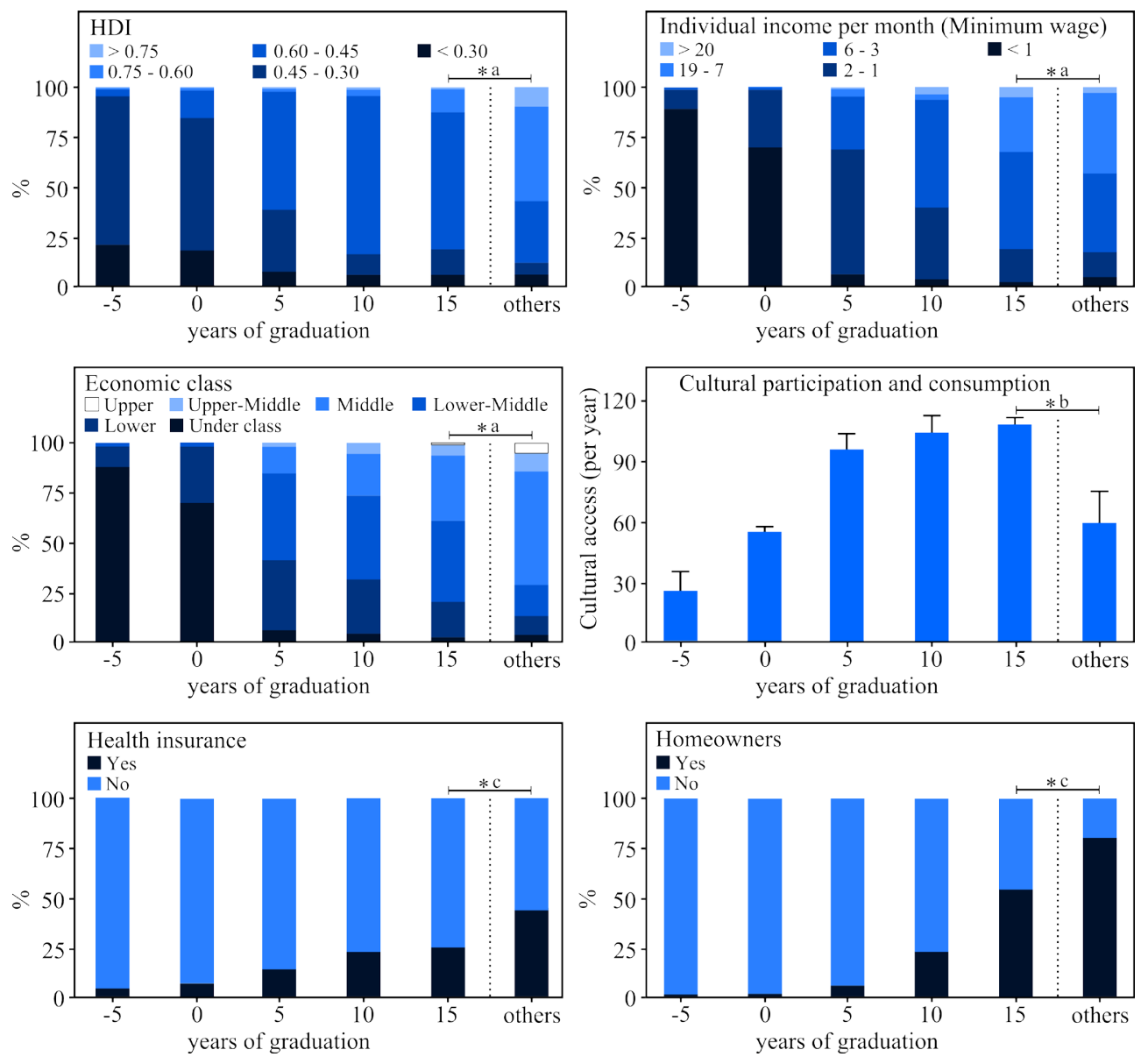

Figure 2. Human development Index (HDI) of neighborhood where teachers lived ( $\mathrm{n}=527,014)$, mean individual income per month (unit: minimum wage), economic class, cultural access, health insurance plan and homeowners status, of graduated teachers and of others graduated professionals $(\mathrm{n}=1,113,639)$ in Brazil. ${ }^{*} p<0.001 ; \mathrm{a}=$ Chi-square Test; $\mathrm{b}=$ Mann-Whitney Test; and $\mathrm{c}=$ Exact Test of Fisher. 
professionals $(0.76, p<0.001)$.The number of analyzed data were of 527,014 teachers and 1,113,639 others graduated professionals, all data in each analyzed variable were on normal distribution $(p<0.001)$. The same rise (from undergraduate to exercise of profession) occurred with the variable mean individual income per month (in minimum wage), but at 15 years of graduation, the value of this variable is lower than to others professionals, 4.3 and 7.9 minimum wages $(p<0.001)$, respectively. The teachers in the most are classified on Lower-Middle economic class (at 15 year of graduation), while the others professionals in the most are on Middle class. Others factor relevant to feature in Brazil about economic class is the insertion in health insurance plan and homeowners status (if they have or have not own home). This insertion and ownership increased over time for the teachers, but the number of teachers that owned homes were lower than others professionals $(p<0.001)$. These data showed the teacher depreciation in Brazil, although the rise of income from origin (undergraduate) to destination (exercise to profession) was observed (without intra and intergenerational mobility). When the students became teachers, this is not guarantee for economic-social mobility. Over time, the cultural access by teachers increased, and this access on mean is higher (113) than practiced by others professionals $(61, p<$ 0.001).This cultural access could represent a cultural mobility, because the occupying of cultural spaces mean an attention of local and contexts needed (Xu \& Hampden-Thompson, 2012).

The distribution of some variables on Brazilian states (Figure 3) highlighted significant correlations. The number of teachers per 100,000 inhabitants were higher in areas with lower HDI values $(\rho=-0.603)$, in areas with lower values of incomes $(\rho=-0.712)$ and in areas with lower numbers of homicides per 100,000 $(\rho=$ -0.901). The most of center-north-northeast states supported the correlations that are regions with high economic inequalities. This highlighted the importance of teacher profession for areas with low HDI, and their indirect
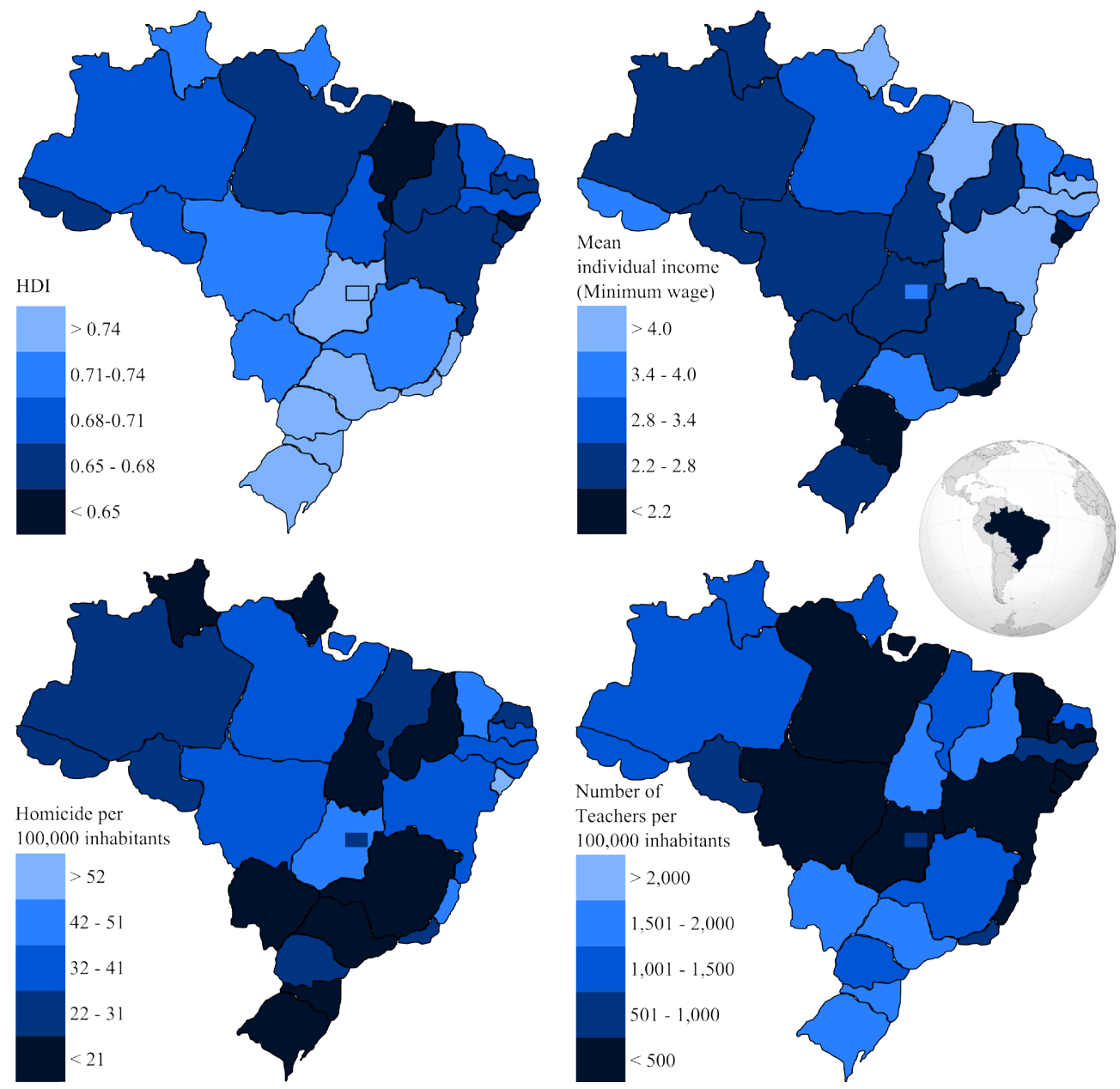

Figure 3. Map distribution per Brazilian state of human development index (per state), mean individual income per month, numbers of homicides per 100,000 inhabitants, and number of teachers per 100,000 inhabitant classes. 
influence in homicide rates. Where exists teachers, exists schools, and exists students occupying activities to construction of subject. These relations was clear when compared with others professions (Figure 4(a)). The most of lawyers, physician and engineers established on areas with high HDI $\left(\mathrm{R}^{2}>0.87, p<0.001\right)$, otherwise with teachers $\left(\mathrm{R}^{2}=0.75, p<0.001\right.$ ). Other data highlighted (Figure $4(\mathrm{~b})$ ), the high presence of teachers was correlated with reduction of homicides per inhabitants $\left(\mathrm{R}^{2}=0.96, p<0.001\right)$, and this relation for others professions was indifferent (not significant, $\mathrm{R}^{2}<0.01, p=0.216$ ). In addition, the variation of family income per month was higher to teachers $(\mathrm{CV} \%=296)$ than the others professions $(\mathrm{CV} \%>30)$ (Figure 4(c)), but this variation did not reflect on economic mobility (see Figure 2).

The most of graduated teachers in Brazil came from lower economic class families and the most of the others studied professions (lawyers, physicians and engineers) came from upper-middle class families. The motivation for lower economic classes becomes teacher could be the easy admission in University (low mentions for student from low quality secondary schools), and for higher economic classes the demotivation to become teacher is the low wages, but could other cause exist to the students become teachers? The qualitative analysis could response this. Another highlight was that in Brazil on areas with low HDI was needed a governmental program of employment for physicians "More Physicians" (Mais Médicos, 2015), because the Brazilian physicians did not accept to go to areas with low HDI. The physicians denounced low incomes and low quality of labor infrastructure (Póvoa \& Andrade, 2006).

Thus, what is really the attractiveness of the teacher profession? Why did students decide be teachers in Brazil? Would the cause be social mobility? The gotten responses of teachers ( $\mathrm{n}=25,013$ interviews $)$ were converged to two topics: 1) "vocational desire" (e.g. capacity of oratory, persuasion and synthesis for public); and 2) "the imaginary transmitted by parents and media discourses of that "the school" (local of fundamental for personal economic growth, of respect and thrust) have moral and knowledge authorities approved by society". The choice vocational could be little pragmatic of high economic classes (Rojewski, 2002). The social immobility is more important for riches than for the poor (Luckmann, 1970). Thus, the people of high economic classes did not desire become teachers, with low wages and work dedication in local with low quality infrastructure. For people
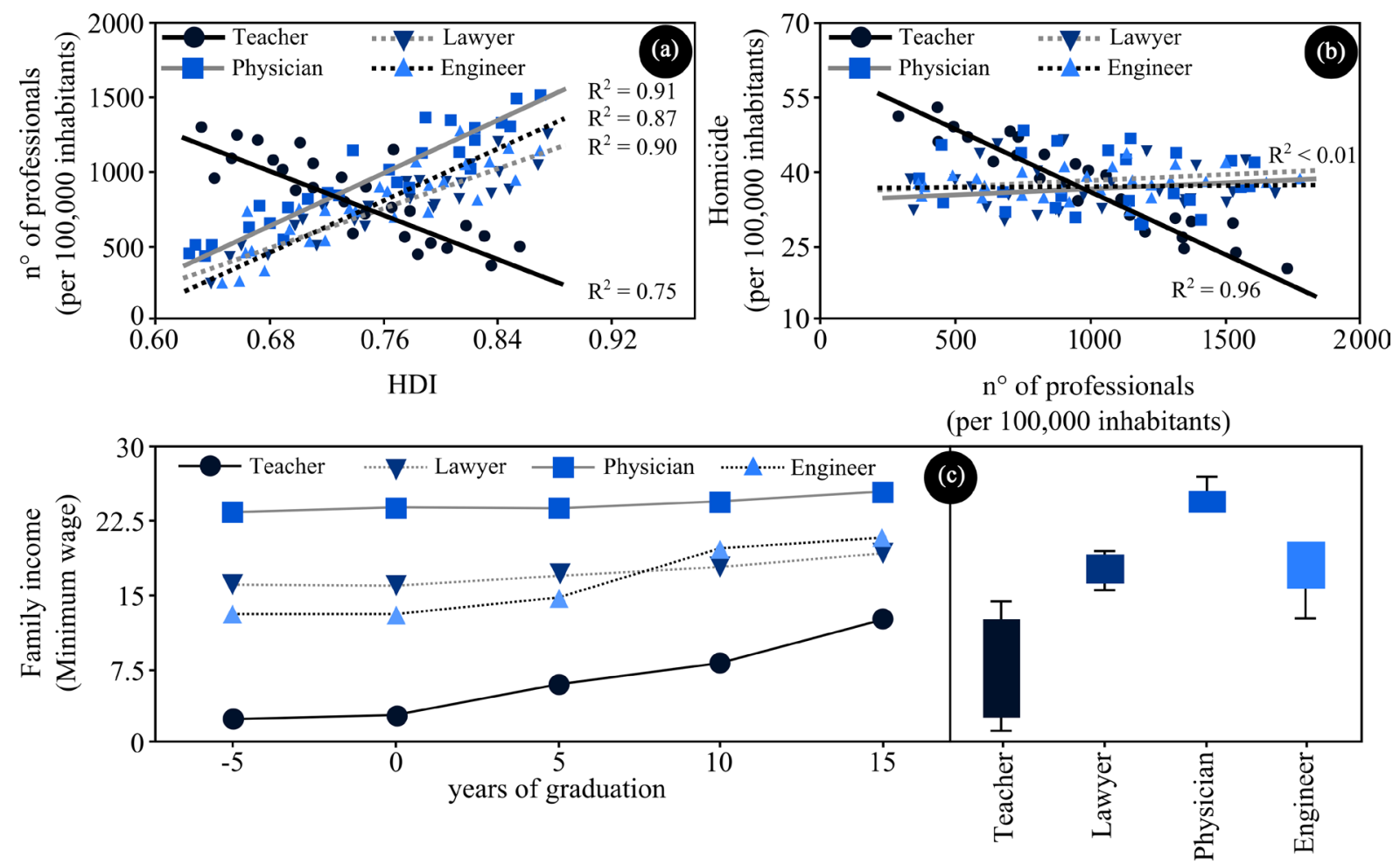

Figure 4. (a) Relation between number of professionals per 100,000 inhabitants and human development Index (HDI); (b) Relation between number of homicides per 100,000 inhabitants and number of professionals per 100,000 inhabitants; (c) Mean family income per month over time. $\mathrm{R}^{2}=$ coefficient of determination of linear regression analysis. Points are mean of each Brazilian state ((a) and (b)). 
from low economic classes become teacher could mean the acceptance in the institutions or the visualization of subject by institutions (Foucault, 1982). When students, the graduated teachers did not report about wages, or social mobility, but when they narrated about school authorities, they would desire a position of supported authority by society. Moreover, in an authority is implied a financial status (imaginary status) that allow to the teachers stay in a high strata imaginary (without money) (Medina, 2011).

In the question: does the academic capital (teacher degree) allow the social mobility?, the responses were divided in two topics: 1) in theory, "the graduation (degree/diploma) is the turning point to social mobility"; 2) in practice, "the degree allows the access to specific labor, but it did not ensure the social mobility". This ambivalence was unanimity from responses. The new worker or producer of goods and services did not necessary got a graduate degree or academic capital (Cabral, 2012). So, what is the importance of graduated teachers on social stratification (their class position)? and, what is the importance of social mobility for teachers to national plan of education and federalism strategies? The responses indicated: "With education the teachers could discuss the social classes and why do we desire a mobility? Just by consumption?”. And this issue is important to national plan of education and federalism strategies. The discussion of status and profession on consume issue is fundamental to discuss the constructed structuralism by capitalism system. Is necessary the structure to be maintained? The education for reduction of class inequalities is more important than an education for developmentalism (Santos, 2000), and the status position constructed on goods is a producer of in equalities (Harvey, 1978). Thus, the empathy of collectives and cultural contexts will be federalism strategies to the development human, instead of capital human formation priority in Brazil.

So, would teachers break with the social reproduction? and, would teachers stimulate the changing of habitus? In all the demarches, the response for these questions was "yes". The university could be conservative, regenerative and generating of knowledge (Morin, 2000), and this last the main for identity of university and of the university agents (local and context needs). Other response of interview to these questions was: "The importance of education is to teach to live in cooperation and in the horizon of equality in relation the institutions (justice)." This breaks would the future of education because it will be support by reduction of consume (freedom principle and sustainability principle) and reduction of inequalities (Moore, 2005).

\section{Conclusion}

In Brazil, from the method perspective of this work, the main conclusion was that most of the graduated teachers do not obtain a social mobility from undergraduate to exercise of profession. The students became teachers by vocational choice and by an imaginary status of teacher in society (knowledge authority). The rise of cultural access by teachers could represent a cultural mobility. The teachers are important for federalism strategies by their disposition of live in areas with lower Human Development and lower incomes than other Brazilian professionals. The presence of teachers in number per inhabitants is related with the low number of homicides per inhabitants, and this could be an important topic to federalism strategies. The breaks with economic habitus (consumption) and social structure in classes could be the future of education way. These breaks are fundamental for the National Plan of Education and for a Project of Nation.

\section{Acknowledgements}

I thank for PROExC/PROPESQ/UFPE by financial support, for Research Group “Interface Biologia e Educação” by discussion, and for "Educometry Blog” (http://educometry.blogspot.com) by survey support.

\section{References}

Benoit-Smullyan, E. (1944). Status, Status Types, and Status Interrelations. American Sociological Review, 9, 151-161. http://www.jstor.org/stable/2086307 http://dx.doi.org/10.2307/2086307

Bourdieu, P., \& Passeron, J. (1977). Reproduction in Education, Society and Culture. London: Sage.

Bourdieu, P. (1986). The Forms of Capital. In J. Richardson (Ed.), Handbook of Theory and Research for the Sociology of Education (pp. 241-258). New York: Greenwood. https://www.marxists.org/reference/subject/philosophy/works/fr/bourdieu-forms-capital.htm

Brasil (2014). NationalPlan of Education-PNE e dá outras providências. Lei n 13.005, de 25 de junho de 2014. http://www.planalto.gov.br/ccivil_03/_Ato2011-2014/2014/Lei/L13005.htm 
Cabral, M. S. A. (2012). Reinventando a educação: Diversidade, descolonização e redes. Petrópolis: Editora Vozes.

Chauí, M. (2013). Uma nova classe trabalhadora. In E. Sader (Ed.), 10 anos de governos pós-neoliberais no Brasil: Lula e Dilma (pp. 123-134). São Paulo: Boitempo Editorial. http://goo.gl/NF9DK9

Davis, K., \& Moore, W. E. (1967). Some Principles of Stratification. In Bendix \& Lisper (Eds.), Class, Status and Power (pp. 242-249). London: Routledge \& Kegan Paul.

http://web.stanford.edu/group/scspi/_media/pdf/Reference\%20Media/Kingsley_Moore_Theory.pdf

Dieese (2015) Departamento Intersindical de estatística e estudos sócios econômicos. Classes sociais no Brasil. http://www.dieese.org.br/

Durkheim, E. (1956). Education and Sociology. New York: Free Press.

Evans, H. (1993). The Choice of Teaching as a Career. Social and Economic Studies, 42, 225-242. http://www.jstor.org/stable/27865902

Featherstone, M. (1987). Lifestyle and Consumer Culture. Theory, Culture \& Society, 4, 55-70. http://dx.doi.org/10.1177/026327687004001003

Foucault, M. (1982). The Subject and Power. Critical Inquiry, 8, 777-795. http://www.jstor.org/stable/i257731 http://dx.doi.org/10.1086/448181

Freire, P. (1987). Pedagogia do oprimido. Rio de Janeiro: Paz e Terra.

Freire, P. (1996). Pedagogia da autonomia: Saberes necessários à prática pedagógica. São Paulo: Paz e Terra.

Gatti, B. A. (2010). Formação de professores no Brasil: Características e problemas. Educação e Sociedade, 31, 1355-1379. http://dx.doi.org/10.1590/S0101-73302010000400016

Go, J. (2000). Chains of Empire, Projects of State: Political Education and US Colonial Rule in Puerto Rico and the Philippines. Comparative Studies in Society and History, 42, 333-362. http://dx.doi.org/10.1017/S0010417500002498 http://journals.cambridge.org/article_S0010417500002498

Harvey, D. (1978). The Urban Process under Capitalism: A Framework for Analysis. International Journal of Urban and Regional Research, 2, 101-131. http://dx.doi.org/10.1111/j.1468-2427.1978.tb00738.x

Havighurst, R. J. (1953). Human Development and Education. Oxford: Longmans, Green.

IBGE, Instituo Brasileiro de Geografia e Estatística (2015). População. http://www.ibge.gov.br/home/

INEP, Instituto Nacional de Estudos e Pesquisas Educacionais Anísio Teixeira (2015). Sinopses Educação Básica. http://portal.inep.gov.br/

Inkscape (2015). Vector Graphics Editor. https://inkscape.org

Lopreato, J., \& Hazelrigg, L. E. (1970). Intragenerational versus Intergenerational Mobility in Relation to Sociopolitical Attitudes. Social Forces, 49, 200-210. http://dx.doi.org/10.1093/sf/49.2.200

Luckmann, T. (1970). On the Boundaries of the Social World. In M. Natanson (Ed.), Phenomenology and Social Reality (pp. 73-100). Amsterdam: Springer. http://dx.doi.org/10.1007/978-94-011-7523-4_5

Mais Médicos (2015). Programa Mais Médicos. http://maismedicos.saude.gov.br/

MEC, Brazilian Ministry of Education (2015). Sistema de Seleção Unificada. http://sisu.mec.gov.br/

Medina, J. (2011). The Relevance of Credibility Excess in a Proportional View of Epistemic Injustice: Differential Epistemic Authority and the Social Imaginary. Social Epistemology, 25, 15-35. http://dx.doi.org/10.1080/02691728.2010.534568

Meighan, R. (1986). A Sociology of Educating. London: Cassell Educational. http://ro.uow.edu.au/cgi/viewcontent.cgi?article=2262\&context=sspapers

Moore, J. (2005). Is Higher Education Ready for Transformative Learning? A Question Explored in the Study of Sustainability. Journal of Transformative Education January, 3, 76-91. http://dx.doi.org/10.1177/1541344604270862

Morenoff, J. D., Sampson, R. J., \& Raudenbush, S. W. (2001). Neighborhood Inequality, Collective Efficacy, and the Spatial Dynamics of Urban Violence. Criminology, 39, 517-558. http://dx.doi.org/10.1111/j.1745-9125.2001.tb00932.x

Morin, E. (2000). Les Sept savoirsnécessaires à l'éducation du futur. Paris: Le Seuil.

Póvoa, L., \& Andrade, M. V. (2006). Distribuição geográfica dos médicos no Brasil: Uma análise a partir de um modelo de escolha locacional. Cadernos de SaúdePública, 22, 1555-1564. http://dx.doi.org/10.1590/S0102-311X2006000800004

Rojewski, J. (2002). Preparing the Workforce of Tomorrow: A Conceptual Framework for Career and Technical Education. Journal of Vocational Education Research, 27, 7-35. http://goo.gl/JkIc07 http://dx.doi.org/10.5328/JVER27.1.7

Santana, O. A. (2011). Docentes de pós-graduação: Grupo de risco de doenças cardiovasculares. Acta Scientiarum Education, 33, 219-226. http://dx.doi.org/10.4025/actascieduc.v33i2.13569 
Santana, O. A. (2013). Alumni from D.E. Teacher Preparation Degrees (Northern Consortiums and UAB: 2001-2012), Employability and Market Absorption. Brazilian Review of Open and Distance Learning, 12, 47-58. http://www.abed.org.br/revistacientifica/_English/2013/3B_Artigo_Rbaad_Ingles_2ed.pdf

Santana, O. A. (2014). Ensino de ciências em Braille com histórias em quadrinhos roteirizados por cegos. Linhas Críticas, 20, 711-743. http://periodicos.unb.br/index.php/linhascriticas/article/view/12666

Santana, O. A. (2015). Divórcios de Docentes de Universidades Federais Brasileiras. Cadernos de Estudos Sociais, $30,61-77$. http://periodicos.fundaj.gov.br/CAD/article/view/1493

Santana, O. A., Silva, T. P., Inácio, E. S. B., Oliveira, G. S., Silva, M. M., \& Encinas, J. I. (2013). Integration of Face-toFace and Virtual Classes Improves Test Scores in Biology Undergraduate Courses on Days with Flooding in Brazil. Acta Scientiarum Education, 35, 117-123.

Santos, M. (2000). Por uma outra globalização—Do pensamento único à consciência universal. São Paulo: Editora Record.

Shumway, D. R. (2000). Fetishizing Fetishism: Commodities, Goods, and the Meaning of Consumer Culture. Rethinking Marxism, 12, 1-15. http://dx.doi.org/10.1080/08935690009358989

UNDP, United Nations Development Program (2010). Human Development Report 2010. New York: UNDP. http://hdr.undp.org/sites/default/files/reports/270/hdr_2010_en_complete_reprint.pdf

Weber, M. (1946). Class, Status, Party. In H. H. Girth, \& C. W. Mills (Eds.), From Max Weber: Essays in Sociology (pp. 180-195). New York: Oxford University. http://www.soc.duke.edu/ jmoody77/TheoryNotes/Weber_CSP.htm

Xu, J., \& Hampden-Thompson, G. (2012). Cultural Reproduction, Cultural Mobility, Cultural Resources, or Trivial Effect? A Comparative Approach to Cultural Capital and Educational Performance. Comparative Education Review, 56, 98-124. http://dx.doi.org/10.1086/661289

Zar, J. H. (1999). Biostatistical Analysis. Upper Saddle River, NJ: Prentice Hall. 